\title{
Zakat Compliance Behaviour: Good Corporate Governance with Muzakki's Trust Approach (Survey on Muzakki of the National Board of Zakat (BAZNAS) in Garut)
}

\section{Nafillan Arofata Tsalas, A. Jajang W.Mahrí, and Rida Rosida}

Department of Islamic Economics and Finance, Indonesia University of Education, Setiabudhi 229, Bandung, Indonesia

\section{Abstract}

Zakat is obligation for every muslim which should be done. Beside the religious orders, zakat is also very influential for regional economic growth, especially the wealth distribution from each capable individual to unable. In Indonesia, the discrepancy between the potential and realization of zakat funds still being a phenomenon that must be resolved. One of the reasons why there is an imbalance between the potential

Corresponding Author: Nafillan Arofata Tsalas inelnafillan@student.upi.edu

Received: 10 February 2019 Accepted: 14 March 2019 Published: 28 March 2019

Publishing services provided by Knowledge E

(c) Nafillan Arofata Tsalas et al. This article is distributed under the terms of the Creative

Commons Attribution License, which permits unrestricted use and redistribution provided that the original author and source are credited.

Selection and Peer-review under the responsibility of the ICIEBP Conference Committee.

\section{G OPEN ACCESS} and realization of zakat funds is because of the disobedience of muzakki in paying zakat. This research identifies the effect of good corporate governance implementation in zakat institutions on zakat paying compliance through muzakki's trust in as a mediating variable. The number of samples used was as much as 100 muzakki spread in several service offices in Garut. The sample was selected using purposive sampling method with quota sampling technique. This study uses path analysis to identify good corporate governance in zakat institutions towards zakat paying compliance through muzakki's trust as a mediating variable by causality method. The results showed that Good corporate governance and muzakki's trust in that zakat institutions were in the high category and muzakki's zakat paying in a high compliance too.

\section{Keywords: Zakat, Compliance, Trust, Governance}

\section{Introduction}

Islam tackles every aspect of society's concerns, whether it is at the spiritual, individual, social, economic or political level, Islam gives clear instructions and directives to individuals in order to go through the rightful path (Lahjouji, 2016).

Zakat has a significant role in the field of economics, as well as having social and moral implications and alleviating poverty. Zakat is an obligatory act for every muslim that command to provide zakat is firmly demonstrated in the Al-Qur'an, where the word 'Zakat' is mentioned 30 times, 27 instances of which are mentioned along with 
the word 'shalat' (Suryaningtyas, 2018). As a predominantly Musli countries, there are several Islmic instruments to increase the economic growh, such as zakat (Beik, 2018).

In Indonesia, zakat also emphasized by Law No. 23 of 2011 that explain, for increasing an effectiveness and efficiency of services in the management of zakat and increasing the benefits of zakat to realize, is by cleaning up the governance system in the form of transparency, accountability and surely will have a positive impact on mustahik, muzakki, and the zakat institutional itself.

Based on the pre-research conducted by the author to the National Board of Zakat (BAZNAS) in West Java Province, according to Dita Agustian, the Head of Funding Divison at BAZNAS West Java Province obtained data that the potential of zakat receipts in Indonesia (national scale) amounting to Rp. 217 Trillion, but in reality only on Rp.6 Trillion collected. There is still a state of numbers that is plain between.

To developed a framework for measuring the efficiency and governance of zakat institutions, the importance of evaluating efficiency and zakat governane is to enable higher rates of zakat productivity, so there is a relationship between efficiency and governance (Mubtadi, 2018). And the purpose of zakat is to improve the welfare of people that is needed the zakat management institution, which can regulate and expand zakat fairly and evenly (Rahmat, 2017).

Arif Ramdani as a chair of BAZNAS Province of West Java, expressed that West Java as one of the most densely populated provinces in Indonesia, has the potential for high-value Zakat funds that reaching Rp. 17,6 Trillion, but still not optimally collected. This was proven in 2016 , West Java wa s only able to collect Rp. 500 billion from zakat, infak, and shodaqoh funds. This is being possible because West Java muslim who pays through zakat institutions, it has not been officially registered or may not have paid zakat, so the potential of zakat has not been maximized yet.

TABLE 1: The Potential and Realization of Zakat according to Province.

\begin{tabular}{l|c|c|} 
Province & $\begin{array}{c}\text { Potential of Zakat } \\
\text { (Trillion) }\end{array}$ & $\begin{array}{c}\text { Realization of } \\
\text { Zakat (Billion) }\end{array}$ \\
\hline West Java & Rp. 17,67 & Rp. 500 \\
\hline East Java & Rp. 15,49 & Rp. 32 (2015) \\
\hline Central Java & Rp. 13,28 & Rp. 300 \\
\hline Source: SCN BAZNAS 2017 &
\end{tabular}

The real collection of zakat fund is still far away from the potential number, this showed that the collection and distribution of zakat fund is still need to be improved continuously and there is an urgent need of regulations that better facilitte the zakat institutions would 
maximize the mobilization of zakat funds and their immediate redistributive economic impact in Indonesia (Saidurrahman, 2013). BAZNAS as national zakat institutions need to make several efforts, namely holding socialization, literacy and education. This is needed with the achievement of a synergy between zakat institutions in a frame of distribution and zakat using (Hafidhuddin, 2013).

It can be concluded that zakat is one of the religious institutions that aims to improve justice and public welfare, BAZNAS as a government zakat institution is obliged to increase the effectivenenss with good management of organizational in accordance with Islamic law. Because, all zakat management processes in an area must be based on the role of zakat management institutions, namely BAZNAS.

Because we have to improve and maintain zakat payers to believe are important in collecting zakat by zakat institutions in order to increase collection, besides that zakat institution is not enough to only use a religious approach, but also must prioritize the principles of good governance, in accordance with the demands of religion and time, and both should to always coincide in all stages of zakat governance, the process, implementation and governance evaluation (Chotib, 2018).

Based on some of the research results of the study by Endriana on 2016 show that the effect of the zakat paying is caused by good corporate governance in zakat institution and Ahmad Kurniawan on 2014 saying that the most significant factor affecting the effevtiveness and an efficiency of the zakat management is the implementation of GCG especially the accountability aspect.

With that background, BAZNAS as national zakat institution is have not implemented the principles of good corporate governance perfectly, that showed by zakat realized is far from the high potential. Creating a good treaty for the organization of Amil Zakat related by the administration system that remains transparent and relevant zakat financial reports, as well as good supervision in the elements of transparency, responsibility, accountability, and fairness. Therefore, the autors are interested to doing a research on the principles of Good Corporate Governance in the government of BAZNAS in Garut.

\section{Literatur Review}

\subsection{Zakat}

Zakat is the third pillar of Islam coming next to Salat in the hierarchy of the five pillars of Islam (Ummulkhayr, 2017). In many Islamic literatures, there has been much explained the meaning and importance of zakat for Muslims. According to (Yuswadi, 2018) the 
meaning of zakat is divided into two, namely: first, according to language, the word zakat has several meanings, namely al-barakatu 'cleanliness', al-namaa' growth and development ', ath-thaharatu', and ash-shalabu.

Second, according to the term, although the scholars put it up with a somewhat different editorial between one and the other, but in principle the same, namely that zakat is part of the property with certain conditions, which Allah Almighty obliges to the owner to be handed over to the rightful to receive it specific requirements as well.

In literal terms (lughat), Zakat can be translated as to cleanseor purify (QS. At-Taubah: 103). Paying Zakat because of belief in Allah undoubtedly will inherit much of goodness in life. Allah SWT says:

"Take, (O, Muhammad), from their wealth a charity by which you purify them and cause them increase, and invoke (Allah's blessings) upon them. Indeed, your invocations area reassurance to them. And Allah is Hearing and Knowing" (QS. At-Taubah: 103)

\subsection{Good corporate governance}

Good governance is a crucial issue in the context of strengthening the performance of zakat institutions as a public organization, the performance of zakat institutions especially in management and service are the benchmark for the growth of public trust (Amalia, 2018). It is important for zakat institution to exhibit excellent zakat operation performance as this sustain the confidence of zakat payers to continue paying zakat in zakat institution (Sapura, 2012).

The definition of Good Corporate Governance is a system which manages and controls the organizations or corporations to create value addition for all stakeholders and the corporate governance structure specifies the distribution of rights and responsibillities among different participants in a corporation, such as the board, the managers, shareholder and other stakeholders and spells out the rules and procedures for making decisions on corporate affairs (Firmansyah, 2017).

According to good corporate governance principles its covering to: a) Transparancy; b) Accountabillity; c) Responsibillity; d) Independency; e) Fairness (Fransiska, 2017). 


\subsection{Muzakki's trust}

Muzzaki's trust is person's willingness to rely others where we have confidence in something, this is a mental condition based on one's situation and social context, as well as the muzakki belief in the zakat institution, muzakki who have been convinced of an amil zakat institution then muzakki will continue to pay his zakat to the zakat institution (Nasim, 2014).

Understanding the behaviour of zakat payers is important to the zakat institutions (Islamic charities), this is because the success of compulsory zakat deduction is contingent upon the level of monetization of the economy, the proportion of apparent and non apparent assets held by Muslims and the degree of confidence reposed by people in official zakat institutions (Mustafa, 2013).

Doubts muzakki to issue a well-founded zakat paying if they lack the understanding and meaning of zakat itself, lacked knowledge on zakat management institutions, will be minimal access to information concerning the use of zakat funds that have been channeled, will be minimal work program of the management information (Taisir, 2017)

Zakat management with more professional,trustworthy and transparent will be developing the spirit of community for spending their zakat (Syafei, 2016). The characteristics of having trust in zakat institutions are: a) the exsistence of long-term relationships; b) increasing the number of zakat funds collected at the time to time; c) being loyal to zakat instituions and doing persuasive activities (Fadillah, 2012).

\subsection{Zakat compliance behaviour}

According to Muhammad Murtadha Az-Zabidi in (Nasution, 2017) the word of compliance means al-inqiyad 'submission', where basically, the main factor of religious people carries out demands on the basis of faith. According to Yadianto in (Nadlifah, 2015) compliance is like according to orders and obedient to orders. While compliance is a behavior that is in accordance with the rules and disciplined. Therefore, the authors draw the conclusion that the characteristic of compliance is the obedient behavior of orders that comply with the rules and do so with discipline.

Associated with the behavior of paying zakat, based on the above understanding compliance is obedience, submission and implementing the provisions of zakat worship. So, the zakat paying compliance is the muzakki who obeys and fulfills and carries out the obligation of zakat in accordance with the provisions of the Shari'a. The effect of worship, knowledge of zakat, wealth or income, role of he ulama, credibility of the 
institution of amil zakat and the role of government, that have partially affected the motivation to pay the zakat (Sedjati, 2018)

Beside that, Understanding zakat payers' compliance behavior is particularly crucial to charity institutions because many Muslims have a political agenda in settling charitable organizations and such adversely affect their trust in them. This attitude against governmental institution led to the emergence of voluntary organizations which filled the gap by collecting and distributing zakat along with other humanitarian donations (Mohamad, 2011)

\section{Methodology}

This study consists of three variables, namely the good corporate governance variable $(X)$ as an independent variable, then the muzakki trust variable to the zakat institution $(Y)$ as an intervening variable, then zakat compliance behaviour $(Z)$ as dependent variable. The survey on muzakki of The National Zakat Board (BAZNAS) in Garut.

Sampling techniques using a purposive sampling approach quota sampling is obtained as many as 100 respondents.

This study analyzes the data using path analysis method. Path analysis is used to "examine the effects directly or indirectly from variables hypothesized as a result of the effect of treatment on these variables and the aim of path analysis is to provide estimates of the magnitude and sagnificance of hypothesized causal connections among sets of variables displayed through the use of path diagrams" (Stage, 2010).

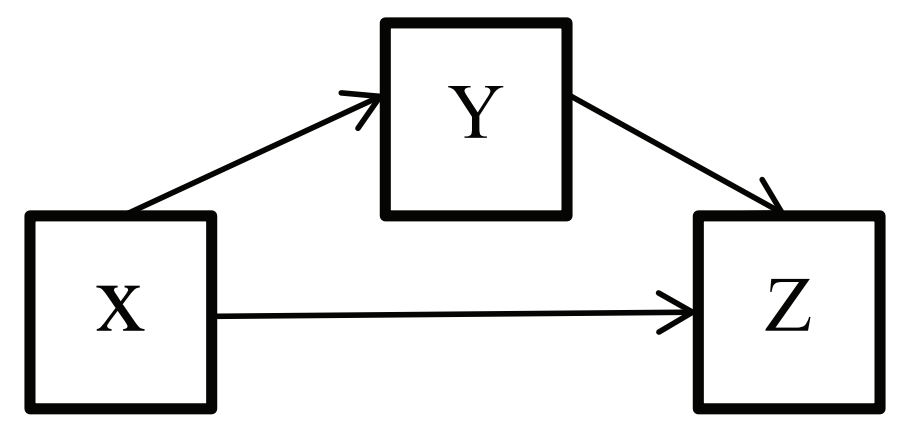

Figure 1: Diagram of Path Analysis method.

\section{Results}

Based on the results of research in the field, known general description of the characteristics of respondents are as follows: 
TABLE 2: Characteristics of Respondents by Gender.

\begin{tabular}{l|c|c|c|} 
No & Gender & $\begin{array}{c}\text { Frequency } \\
\text { (person) }\end{array}$ & $\begin{array}{c}\text { Persentage } \\
\text { (\%) }\end{array}$ \\
\hline 1 & Male & 42 & $42 \%$ \\
\hline 2 & Female & 58 & $58 \%$ \\
\hline & Total & 100 person & $100 \%$ \\
\hline
\end{tabular}

Based on the gender characteristi, thats table showing more female respondents than male, because based on the facts on the existence of civil servants that the author studied, more female employees worked in the official office. In addition, some male work in the Office of Service, tended to work outside the office (part of the field), so that it was sometimes difficult to find respondents to study. Therefore there are fewer women respondents who actually work in the office.

TABLE 3: Characteristics of Respondents by Age.

\begin{tabular}{|l|c|c|c|}
\hline No & Age & $\begin{array}{c}\text { Frequency } \\
\text { (person) }\end{array}$ & Persentage (\%) \\
\hline 1 & $36-40$ & 27 & $27 \%$ \\
\hline 2 & $41-45$ & 31 & $31 \%$ \\
\hline 3 & $46-50$ & 13 & $13 \%$ \\
\hline 4 & $51-55$ & 21 & $21 \%$ \\
\hline 5 & $56-60$ & 8 & $8 \%$ \\
\hline & Total & 100 person & $100 \%$ \\
\hline
\end{tabular}

Based on table 3, it can be seen that the age of Civil Servants who are actively working in the age range of 41 to 45 years indicated by the graph is at $31 \%$. While there are at least a number of Civil Servants in the age range of 36 to 40 years indicated by the graph at $8 \%$. It can be concluded that the Civil Servants studied by the author are at the age of 40 years and over.

Based on Table 5, it is very explicit that in all the sub-level education that the most recent research author is the bachelor level, because the bachelor is currently the minimum standard to work for most institutions.

Based on that tables, it show that from the researched by the author, has become active Muzakki in BAZNAS Garut is dominated by Muzakki active for 2 years. This means, Muzakki who paid his zakat has begun to be active since the start of the working period of the BAZNAS Garut under of Mr. Rd. Aas Kosasih leadership who was inducted in 2016. 
TABLE 4: Characteristics of Respondents by Level Education.

\begin{tabular}{|l|c|c|c|}
\hline No & \begin{tabular}{c} 
Level of Education \\
\hline 1
\end{tabular} & $\begin{array}{c}\text { Frequency } \\
\text { (person) }\end{array}$ & Persentage (\%) \\
\hline 2 & $\begin{array}{c}\text { Senior High } \\
\text { School }\end{array}$ & $24 \%$ \\
\hline 3 & Bachelor & 56 & $56 \%$ \\
\hline & Master & 20 & $20 \%$ \\
\hline
\end{tabular}

TABLE 5: Characteristics of Respondents by the time being Muzakki.

\begin{tabular}{|c|c|c|}
\hline No & 1 year (person) & 2 years (person) \\
\hline 1 & 26 & 74 \\
\hline & Total & 100 person \\
\hline
\end{tabular}

The variables of Good Corporate Governance in this study were measured using five indicators, namely Transparency, Accountability, Responsibility, Independence, and Fairness. That five indicators are outlined into 12 statements that are used as a measure of the variable Good Corporate Governance in Muzakki that the author carefully based on the calculation of 100 respondents with the following data:

As a discussion, regarding the Good Corporate Governance at BAZNAS Garut in the survey according to 100 respondents, it is in the high category, with each indicator in the range between $63 \%-75 \%$ or in the high category as well. Transparency (Transparency) at BAZNAS Garut, srongly maintains objectivity in carrying out operational activities, BAZNAS Garut provides and relevant information in the ways that are easily accessible and understood by stakeholders (muzakki and mustahik).

In accountability side, institutions must be able to account for their performance transparently and fairly.BAZNAS Garut has a 63 percent accountability level in the muzakki view as respondents. Accountability is a requirement that is needed to achieve sustainable performance, one of which LAZ must periodically issue financial statements and the BAZNAS Garut has carried out this and was successfully audited in April 2018.

BAZNAS Garut, in terms of responsibility related to zakat funds received and managing the distribution has also been in the high category, because in the implication also in the zakat fund distribution programs in BAZNAS Garut has been effective and regardless of the intervention of other parties because HR profesionality in giving rights and obligations to mustahik, muzakki, and amilin. 
TABLE 6: Categorization Score of Good Corporate Governance Variable.

\begin{tabular}{|c|c|c|c|}
\hline Score $\Sigma$ & Max score & $\%$ & Category \\
\hline 328 & 500 & 66 & \\
\hline 332 & 500 & 66 & \\
\hline 326 & 500 & 65 & \\
\hline 986 & 1500 & 66 & High \\
\hline 344 & 500 & 69 & \\
\hline 370 & 500 & 74 & \\
\hline 290 & 500 & 58 & \\
\hline 318 & 500 & 64 & \\
\hline 247 & 500 & 49 & \\
\hline 1569 & 2500 & 63 & High \\
\hline 322 & 500 & 64 & \\
\hline 322 & 500 & 64 & High \\
\hline 399 & 500 & 80 & \\
\hline 352 & 500 & 70 & \\
\hline 751 & 1000 & 75 & High \\
\hline 325 & 500 & 65 & \\
\hline 325 & 500 & 65 & High \\
\hline 3953 & 6000 & 66 & High \\
\hline
\end{tabular}

TABLE 7: Categorization Score of Muzakki's Trust Variable.

\begin{tabular}{|l|c|c|c|}
\hline Score $\sum$ & Max Score & $\%$ & Category \\
\hline 252 & 500 & 50 & \\
\hline 287 & 500 & 57 & \\
\hline 539 & 1000 & 53,5 & Medium \\
\hline 286 & 500 & 57 & \\
\hline 285 & 500 & 56 & \\
\hline 571 & 1000 & 56,5 & Medium \\
\hline 393 & 500 & 79 & \\
\hline 324 & 500 & 65 & \\
\hline 717 & 1000 & 72 & High \\
\hline 1827 & 3000 & 60,9 & High \\
\hline
\end{tabular}

Its seen that the muzakki's trust in the Zakat Institution is in the high category. However, judging from the numbers, it shows a very thin difference from the medium 
category where it explains that it is basically BAZNAS Garut still considered less innovative in carrying out activities specifically related to muzakki, so that muzakki are still limited to persuasive activities in who have not been active in paying zakat to the low category muzakki.

Muzakki's participation in zakat institutions tends to be low category. In the statement about direct communication or indirectly related to the activities of the programs carried out by BAZNAS as well as statements about the participation of the muzakki in the programs carried out by BAZNAS, Averaged in the medium category or in the percentage of $53.5 \%$ including mustahiq rather than muzakki, this can also be caused by BAZNAS having many programs to distribute zakat funds in mustahiq rather than procuring programs with muzakki.

TABLE 8: Categorization Score of Zakat Compliance Behaviour.

\begin{tabular}{|l|c|c|c|}
\hline Score $\Sigma$ & Max Score & $\%$ & Category \\
\hline 430 & 500 & 86 & \\
\hline 331 & 500 & 66 & \\
\hline 761 & 1000 & 76,1 & High \\
\hline 428 & 500 & 86 & \\
\hline 335 & 500 & 67 & \\
\hline 763 & 1000 & 76,5 & High \\
\hline 1524 & 2000 & 76,2 & High \\
\hline
\end{tabular}

Viewed from the table, zakat compliance behaviour for all respondents that the author studied in five government departments is in the high category, with details: for the first indicator, Muzakki pays zakat income to BAZNAS already in the high category, this is due to the direct deduction of income to pay zakat income which results in high suitability and timeliness. It's not different from the payment of zakat fitrah to BAZNAS with the accuracy of paying it already in the high category. This is also due to the appropriateness of size in paying zakat fitrah and standard time in paying zakat fitrah which is during the month of Ramadan before Eid al-Fitr.

And in below of this, there is a table of effect decomposition between variables used to determine the direct and indirect effects of each variable in the research model:

Based on the results of the calculation, the research hypothesis of the equation model sub-structure 1 ( $X$ against $Y$ ) states that, the path coefficients $X$ to $Y$ with the good corporate governance hypothesis affect the muzakki's trust directly can be received with an effect of 0.70 or $70 \%$. 
TABLE 9

\begin{tabular}{|c|c|c|c|}
\hline \multirow{2}{*}{$\begin{array}{l}\text { The effect } \\
\text { between variable }\end{array}$} & \multicolumn{2}{|c|}{ Causal Effect } & \multirow[t]{2}{*}{ Total } \\
\hline & Direct & Indirect (through Y) & \\
\hline$X$ against $Y$ & 0,701 & & 0,701 \\
\hline$X$ against $Z$ & 0,222 & $(0,222 \times 0,467)=0,103$ & 0,325 \\
\hline$Y$ against $Z$ & 0,467 & & 0,467 \\
\hline
\end{tabular}

The research hypothesis of the sub-structure 2 models ( $X$ against $Z$ ) can be explained through the results of calculations with an explanation of data interpretation which states that, the path coefficient $X$ to $Z$ with the good corporate governance hypothesis does not directly affect compliance with paying zakat. Therefore, indirect or through $\mathrm{Y}$ influence can be accepted with the total effect of 0.325 or $32.5 \%$.

Then the path coefficient $Y$ against $Z$ with Muzakki's trust influences the compliance of paying zakat directly can be received with the effect of 0.467 or $46.7 \%$.

\section{Conclusion}

Based on the results of research and discussion of the previous chapter, it can be concluded that the level of implementation of Good Corporate Governance in BAZNAS Garut is in the high category. Then the muzakki's trust in the zakat institution and the zakat compliance behaviour is in the high category.

This is because the amount of zakat funds received by the BAZNAS Garut from the five objects studied are in large numbers, meaning that Muzakki already has trust in the zakat institution. Then Good corporate governance has a significant effect on trust in zakat institutions. This is because the state of muzakki who continues to pay zakat to the BAZNAS Garut continuously shows the trust in the zakat institution.

Furthermore good corporate governance does not affect the compliance of paying zakat. This is because muzakki must have confidence in the charity institution first, then can have compliance in paying zakat to the zakat institution.

Talking about trust in zakat institutions has a significant effect on compliance with paying zakat, logically this can also be accepted, if someone already has trust, surely he will also have a good level of compliance. Finally, good corporate governance has a significant effect on compliance with paying zakat through trust in zakat institutions as an intervening variable. This is indicated by the results of the path analysis regression 
test, where if GCG is tested directly into the compliance variable, the results have no effect. Different if we place trust as an intervening variable, GCG affects the compliance of paying zakat.

\section{References}

[1] Amalia, E. (2018). Good Governance in Strengthening the Performance of Zakat Institutions in Indonesia. International Journal of ICIFEB Conference Committee, 1-9.

[2] Beik, I. S. (2018). Measuring National Zakat Index (Nzi) On Zakat Performance In Bogor Regency. Journal of Islamic Monetary Economics and Finance Vol 3.

[3] Chotib, M. (2018). Implementation of Good Amil Governance at Amil Zakat Institution. International Journal ofHumanities and Social Science Invention, 93-100.

[4] Fadillah, S. (2012). Penerapan Good Fovernance Pada Lembaga Amil Zakat. Bandung: UNPAD Press.

[5] Firmansyah, I. (2017). The Implementation Strategies of Good Corporate Governance for Zakat Institutions in Indonesia. International Journal of Zakat Vol.2, 85-97.

[6] Fransiska, M. (2017). Urgensi diterapkannya Prinsip Good Corporate Governance (GCG) pada Pengelolaan Perusahaan Daerah. E-Journal UNDIP, 183.

[7] Hafidhuddin, D. (2006). Hukum Zakat: Studi Komparatif mengenai status dan filsafat zakat berdasarkan Quran dan Hadis. Pustaka Litera Antarnusa.

[8] Hafidhuddin, D. (2013). Analisis efektivitas promosi lembaga amil zakat dalam penghimpunan zakat bagi peningkatan kesejahteraan keluarga dhuafa (Studi Kasus Lembaga Amil Zakat Dompet Dhuafa Republika). Media Gizi dan Keluarga.

[9] Lahjouji, H. (2016). Zakat and Distribution of Wealth on Islamic Economy: Case of Morocco. International Journal of Islamic Economics and Finance Studies.

[10] Mohamad, M. H. (2011). Antecedents Of Zakat Payers' Trust: The Case Of Nigeria. Islamic Economics Journal.

[11] Mubtadi, N. A. (2018). Analysis of Governance and Efficiency on Zakat Distribution: Evidence From Indonesia. International Journal of Zakat Vol. 3, 1-15.

[12] Mustafa, M. O. (2013). Antecedents of zakat payers trust in an emerging zakat sector: an exploratory study. Journal of Islamic Accounting and Business Research Vol.4 No 1, 4-25.

[13] Nadlifah, W. (2015). Pengaruh Transparasi dan Tanggung Jawab (Resposibility) . Universitas Islam Negeri Maulana Malik Ibrahim. 
[14] Nasim, A. (2014). Pengaruh Transparansi Laporan Keuangan, Pengelolaan Zakat, dan Sikap Pengelola Terhadap Tingkat Kepercayaan Muzakki. Jurnal Riset Keuangan dan Akuntansi.

[15] Nasution, J. (2017). Analisis kepatuhan membayar zakat terhadap keberkahan. Jurnal Dompet Dhuafa.

[16] Rahmat, R. (2017). Transparansi dan Akuntabilitas Pengelolaan Zakat, Infaq, Shadaqah (Studi Kasus pada Badan Amil Zakat Nasional Kabupaten Buleleng). Jurnal Akuntansi, 1-10.

[17] Saidurrahman. (2013). The Politics of Zakat Management in Indonesia (The Tension Between BAZ and LAZ). Journal of Indonesian Islam, 3-17.

[18] Sapura, H. M. (2012). Good Governance in Zakat Distribution:Perceptions Of Zakat Recipients at Kota Tinggi, Johor. International Journ/s Confrence Paper, 2-7.

[19] Sedjati, D. P. (2018). Analysis of Factors Affecting the Payment of Zakat in Special Capital Region (DKI) of Jakarta, Indonesia. The International Journal Of Business \& Management, 92-103.

[20] Stage, F. K. (2010). Path Analysis: An Introduction and Analysis of a Decade of Research. The Journal of Educational Research New York University, 3-10.

[21] Suryaningtyas, R. (2018). Analysis of BAZNAS Tangerang District Performance. International Journal of Zakat Vol.3, 57-53.

[22] Syafei, Z. (2016). The Increasing of Zakat Management toward Muzakkis' Trust at the Office of Religious Affairs. The International Journal of Social Sciences and Humanities Invention, 3158-3170.

[23] Taisir, M. (2017). Zakat Governance and Muzakki Trust: Between Zakat with Heart and Zakat Due Regulation. International Conference and Call for Papers, 2-21.

[24] Ummulkhayr, A. (2017). Determinants of Zakat Compliance Behavior among Muslims Living in under Non-Islamic Government. International Journal of Zakat, 95-108.

[25] Yuswadi, H. (2018). Implementation of Good Corporate Governance (Amil) at LAZ. IJHSSI, 100. 